\title{
Preferential alteration of oxidative relative to total glycolysis in pancreatic islets of two rat models of inherited or acquired Type 2 (non-insulin-dependent) diabetes mellitus
}

\author{
M.-H. Giroix ${ }^{1}$, A.Sener ${ }^{2}$, B.Portha ${ }^{1}$ and W.J. Malaisse ${ }^{2}$ \\ ${ }^{1}$ Laboratory of Nutrition Physiopathology, CNRS URA 307, University of Paris 7, Paris, France \\ ${ }^{2}$ Laboratory of Experimental Medicine, Brussels Free University, Brussels, Belgium
}

\begin{abstract}
Summary. In islets from both adult rats injected with streptozotocin during the neonatal period and spontaneously diabetic rats obtained by repeated selective breedings (GK rats), the ratio between $\mathrm{D}-\left[3,4-{ }^{14} \mathrm{C}\right]$ glucose oxidation and $\mathrm{D}$ $\left[5-{ }^{3} \mathrm{H}\right]$ glucose conversion to ${ }^{3} \mathrm{HOH}$ was $25 \%$ lower than in islets from control rats, indicating an impaired contribution of oxidative to total glycolysis. No primary defect in the Krebs cycle was found in the islets of diabetic rats, as judged from the ratio between either $\mathrm{D}-\left[2-{ }^{-14} \mathrm{C}\right] \mathrm{glucose}$ or $\mathrm{D}-\left[6{ }^{-14} \mathrm{C}\right] \mathrm{glucose}$
\end{abstract}

and $\mathrm{D}-\left[3,4-{ }^{-14} \mathrm{C}\right]$ glucose oxidation. Therefore, we propose that a preferential alteration of oxidative glycolysis in the pancreatic beta cell may contribute to the impairment of glucose-induced insulin release not only in a cytotoxic but also in a spontaneous model of non-insulin-dependent diabetes mellitus.

Key words: Pancreatic islets, GK rats, streptozotocin, glucose metabolism.
The impairment of glucose-induced insulin release in noninsulin-dependent diabetes mellitus has been suggested to be caused by a defect of $D$-glucose transport across the islet beta-cell plasma membrane $[1,2]$. It is also conceivable, however, that such an impairment is due to a more distal anomaly in $\mathrm{D}$-glucose metabolism, e.g. at the level of its phosphorylation or oxidative catabolism. The present report reveals that, in two experimental models of non-insulin-dependent diabetes, namely in adult rats injected with streptozotocin during the neonatal period (STZ rats) and in spontaneously glucose-intolerant rats $[3,4] \mathrm{ob}-$ tained by selective breeding over numerous generations (GK rats), the oxidation of $\mathrm{D}-\left[3,4-{ }^{14} \mathrm{C}\right]$ glucose by pancreatic islets is impaired even when expressed relative to total glycolytic flux. Therefore, we propose that a perturbation of mitochondrial oxidative events, rather than hexose transport, plays an essential role in the secretory defect.

\section{Materials and methods}

Control Wistar rats, animals injected with STZ [5] during the neonatal period (STZ rats) and GK rats [6] were given free access to food [7]. The rats were weighed and then decapitated. Blood was collected in heparinized tubes for the measurement of plasma glucose by the glucose oxidase method [8] and plasma insulin by radioimmunoassay [9]. In each experiment, islets were isolated by the collagenase method [10] from the pancreas of two rats in each group. Two groups of ten islets each were used for the measurement of islet pro- tein and insulin content $[10,11]$. For the measurement of ${ }^{14} \mathrm{C}$-labelled $\mathrm{D}$-glucose oxidation and $\mathrm{D}-\left[5-{ }^{3} \mathrm{H}\right]$ glucose utilization, groups of ten islets each were incubated for $120 \mathrm{~min}$ at $37^{\circ} \mathrm{C}$ in $40 \mu \mathrm{l}$ of a bicarbonate-buffered medium [10] containing bovine serum albumin $(5 \mathrm{mg} / \mathrm{ml})$. In some experiments, the incubation medium was deprived of $\mathrm{CaCl}_{2}$ and contained $0.5 \mathrm{mmol} / \mathrm{EGTA}$. The production of ${ }^{14} \mathrm{CO}_{2}$ and ${ }^{3} \mathrm{HOH}$ was measured as previously described [12]. The acidified medium containing the islets was stored at $-20^{\circ} \mathrm{C}$ and later examined for its content in ${ }^{14} \mathrm{C}$-labelled amino acids and acidic metabolites separated by ion-exchange chromatography $[13,14]$.

\section{Statistical analysis}

All results were expressed as mean $\pm \mathrm{SEM}$, together with the number of individual observations $(n)$, and were compared using Students unpaired $t$-test.

\section{Results}

\section{Metabolic and hormonal status}

The GK rats were somewhat older $(p<0.001)$ and, yet, displayed a lower body weight $(p<0.05)$ than the control and STZ rats (Table 1). In the fed state, the plasma glucose concentration was higher $(p<0.01)$ in STZ and GK than control rats. The plasma insulin concentration was not significantly different among the three groups of rats. 
Table 1. Metabolic and hormonal status of control rats, animals injected neonatally with streptozotocin (STZ) and GK rats

\begin{tabular}{lccc}
\hline Rats & Control & STZ & GK \\
\hline Age (days) & $96.5 \pm 0.3$ & $96.5 \pm 0.3$ & $119.5 \pm 0.3$ \\
Body weight $(\mathrm{g})$ & $360.5 \pm 18.6$ & $367.3 \pm 13.9$ & $314.5 \pm 16.9$ \\
Plasma glucose $(\mathrm{mmol} / 1)$ & $7.62 \pm 0.19$ & $9.62 \pm 0.33$ & $9.41 \pm 0.69$ \\
Plasma insulin $(\mu \mathrm{U} / \mathrm{ml})$ & $71 \pm 9$ & $67 \pm 1$ & $88 \pm 20$ \\
Plasma insulin/ & & & \\
glucose $(\mathrm{U} / \mathrm{mol})$ & $9.3 \pm 1.3$ & $6.8 \pm 0.1$ & $9.2 \pm 1.8$ \\
Islet insulin $(\mu \mathrm{U} /$ islet$)$ & $954 \pm 42$ & $346 \pm 71$ & $405 \pm 58$ \\
Islet protein $(\mu \mathrm{g} /$ islet $)$ & $0.85 \pm 0.15$ & $0.93 \pm 0.20$ & $0.59 \pm 0.10$ \\
$\begin{array}{l}\text { Islet insulin/protein } \\
\text { (mU/ } / \mathrm{gg})\end{array}$ & $1.23 \pm 0.20$ & $0.47 \pm 0.16$ & $0.74 \pm 0.19$ \\
\hline
\end{tabular}

Mean values ( \pm SEM) refer to four or more individual observations

The mean plasma insulin/glucose ratio was decreased $(p<0.10)$ only in the STZ rats. The insulin content of the islets was severely decreased in both STZ and GK rats $(p<0.001)$. The islet protein content was not affected in STZ rats and slightly but not significantly lower in GK than control rats. The insulin/protein islet content was significantly decreased in STZ rats $(p<0.03)$, but not $(p>0.16)$ in GK rats. When considering the latter findings, it should be noted that only well-identified, relatively large islets were collected from either control or diabetic rats.

\section{D- $\left[5-{ }^{3} H\right]$ glucose conversion to ${ }^{3} \mathrm{HOH}$}

As judged from the conversion of $\mathrm{D}-\left[5-{ }^{3} \mathrm{H}\right]$ glucose to ${ }^{3} \mathrm{HOH}$, the rate of glycolysis was not significantly different in control and STZ rats (Table 2). In the GK rats, the glycolytic flux, when expressed per islet, was lower than the control value $(p<0.001)$ only at a high concentration of $\mathrm{D}$ glucose $(16.9 \mathrm{mmol} / \mathrm{l})$. This difference was no longer observed, however, when the rate of glycolysis recorded in the presence of $16.9 \mathrm{mmol} / \mathrm{l} \mathrm{D}$-glucose was expressed relative to the islet protein content. The results then averaged $250.7 \pm 11.7$ and $252.2 \pm 20.5 \mathrm{pmol} / 120 \mathrm{~min}$ per $\mu \mathrm{g}$ in control and GK rats, respectively.

The relative magnitude of the increase in glycolysis attributable to a rise in the D-glucose concentration was less marked in STZ and GK than control rats. Thus the $16.9 \mathrm{mmol} / \mathrm{l}$ to $5.1 \mathrm{mmol} / \mathrm{l} \mathrm{ratio}$ in ${ }^{3} \mathrm{HOH}$ production averaged 2.11 \pm 0.13 in STZ rats and 2.08 \pm 0.16 in GK rats, as compared $(p<0.02$ or less) to $2.61 \pm 0.14$ in control animals.

At $16.9 \mathrm{mmol} / \mathrm{l} \mathrm{D}$-glucose, the mean production of ${ }^{3} \mathrm{HOH}$ from $\mathrm{D}-\left[5-{ }^{3} \mathrm{H}\right]$ glucose was always slightly lower in the absence than presence of $\mathrm{Ca}^{2+}$, but this difference failed to achieve statistical significance.

\section{$\mathrm{D}-\left[3,4-{ }^{14} \mathrm{C}\right]$ glucose oxidation}

To avoid the interference of differences in islet size, all oxidative data were expressed relative to the paired production of ${ }^{3} \mathrm{HOH}$ from $\mathrm{D}-\left[5_{-}{ }^{3} \mathrm{H}\right]$ glucose. The oxidation of $\mathrm{D}-$ $\left[3,4-{ }^{14} \mathrm{C}\right]$ glucose will be considered first as it provides information concerning the rate of oxidative glycolysis as coupled to the decarboxylation of pyruvate in the reaction catalysed by pyruvate dehydrogenase [14].

In either control, STZ or GK rats, a rise in D-glucose concentration from 5.1 to $16.9 \mathrm{mmol} / \mathrm{l}$ increased the oxidation of $\mathrm{D}-\left[3,4-{ }^{14} \mathrm{C}\right]$ glucose relative to the utilization of $\mathrm{D}-\left[5-{ }^{3} \mathrm{H}\right]$ glucose (Table 2 ). By comparing the data collected within each experiment, such an increase was most obvious in control rats $(p<0.001)$, still evident in STZ rats $(p<0.03)$, but of doubtful significance $(p<0.08)$ in GK rats. At the high hexose concentration, the mean ratio between $\mathrm{D}-\left[3,4-{ }^{14} \mathrm{C}\right]$ glucose oxidation and $\mathrm{D}-\left[5-{ }^{3} \mathrm{H}\right]$ glucose utilization was lower in the absence than presence of extracellular $\mathrm{Ca}^{2+}$. Once again, such a difference was highly significant $(p<0.01)$ in control rats, whilst failing to achieve statistical significance in either STZ or GK rats.

Most importantly, the absolute values for the paired ratio between $\mathrm{D}-\left[3,4-{ }^{14} \mathrm{C}\right]$ glucose oxidation and $\mathrm{D}-[5-$ $\left.{ }^{3} \mathrm{H}\right]$ glucose utilization were much lower $(p<0.01)$ in STZ or GK than control rats, whether at low or high concentration of D-glucose or in the presence or absence of $\mathrm{Ca}^{2+}$. Pooling all available data, such a ratio averaged in STZ and GK rats, respectively, $74.4 \pm 2.7$ and $72.7 \pm 3.2 \%$ ( $p<0.001$ in both cases) of the corresponding mean value found in control rats $(100.0 \pm 2.4 \% ; n=27$ to 35$)$.

A comparable trend was observed for ${ }^{14} \mathrm{C}$-labelled amino acids generated from $\mathrm{D}-\left[3,4{ }^{14} \mathrm{C}\right]$ glucose. Thus, when expressed relative to the paired formation of ${ }^{3} \mathrm{HOH}$ from $\mathrm{D}-\left[5-{ }^{3} \mathrm{H}\right]$ glucose, the production of ${ }^{14} \mathrm{C}$-labelled amino acids, which correspond mainly to the net generation of $\mathrm{L}-\left[1-{ }^{14} \mathrm{C}\right]$ alanine [14], averaged in the STZ and GK rats, respectively, $76.0 \pm 11.0 \% \quad(\mathrm{n}=17)$ and

Table 2. D-glucose metabolism in islets from control rats, animals injected neonatally with streptozotocin (STZ) and GK rats

\begin{tabular}{|c|c|c|c|c|c|c|}
\hline \multirow{2}{*}{$\begin{array}{l}\text { Rats } \\
\text { (Type) }\end{array}$} & \multirow{2}{*}{$\begin{array}{l}\text { D-glucose } \\
(\mathrm{mmol} / \mathrm{l})\end{array}$} & \multirow{2}{*}{$\begin{array}{l}\mathrm{Ca}^{2+} \\
(\mathrm{mmol} / \mathrm{l})\end{array}$} & \multirow{2}{*}{$\begin{array}{l}\mathrm{D}-\left[5-{ }^{3} \mathrm{H}\right] \text { glucose to }{ }^{3} \mathrm{HOH} \\
\text { (pmol/120 min per islet) }\end{array}$} & \multicolumn{3}{|c|}{$\mathrm{D}$-glucose oxidation/D- $\left[5-{ }^{3} \mathrm{H}\right]$ glucose utilization $(\%)$} \\
\hline & & & & $\mathrm{D}-\left[3,4-{ }^{14} \mathrm{C}\right] \mathrm{glucose}$ & $\mathrm{D}-\left[6^{-14} \mathrm{C}\right] \mathrm{glucose}$ & $\mathrm{D}-\left[2-{ }^{14} \mathrm{C}\right]$ glucose \\
\hline Control & $\begin{array}{r}5.1 \\
16.9 \\
16.9\end{array}$ & $\begin{array}{l}1.0 \\
1.0 \\
\text { Nil }\end{array}$ & $\begin{array}{c}81.2 \pm 4.8(36) \\
212.1 \pm 9.9(35) \\
194.9 \pm 13.2(36)\end{array}$ & $\begin{array}{l}60.0 \pm 3.2(11) \\
77.0 \pm 2.6(12) \\
65.6 \pm 2.8(12)\end{array}$ & $\begin{array}{l}20.4 \pm 1.0(12) \\
26.8 \pm 0.6(12) \\
20.1 \pm 0.5(12)\end{array}$ & $\begin{array}{l}42.4 \pm 2.1(12) \\
51.9 \pm 2.1(11) \\
46.7 \pm 2.9(12)\end{array}$ \\
\hline STZ & $\begin{array}{r}5.1 \\
16.9 \\
16.9 \\
\end{array}$ & $\begin{array}{l}1.0 \\
1.0 \\
\text { Nil } \\
\end{array}$ & $\begin{array}{c}95.9 \pm 7.5(35) \\
204.7 \pm 16.1(36) \\
181.5 \pm 9.9(36)\end{array}$ & $\begin{array}{l}43.2 \pm 3.3(11) \\
55.2 \pm 3.7(11) \\
47.9 \pm 2.3(12)\end{array}$ & $\begin{array}{l}19.7 \pm 1.1(11) \\
21.0 \pm 0.8(12) \\
18.0 \pm 0.4(12) \\
\end{array}$ & $\begin{array}{l}36.4 \pm 1.8(12) \\
47.3 \pm 2.5(12) \\
33.7 \pm 1.8(12) \\
\end{array}$ \\
\hline
\end{tabular}


$73.9 \pm 10.6 \%(n=13)$ of the mean corresponding value found within the same experiments and under the same incubation conditions in control rats $(100.0 \pm 12.0 \%$; $n=18$ ). In the latter animals, the absolute value for the paired ratio between the generation of ${ }^{14} \mathrm{C}$-labelled amino acids from $\mathrm{D}-\left[3,4-{ }^{14} \mathrm{C}\right]$ glucose and the utilization of $\mathrm{D}-[5-$ ${ }^{3} \mathrm{H}$ ]glucose averaged $7.9 \pm 1.2 \%$ in the presence of $\mathrm{Ca}^{2+}$ and at high hexose concentration $(16.9 \mathrm{mmol} / \mathrm{l})$. Whether in control, STZ or GK rats, such a paired ratio was higher at 5.1 than $16.9 \mathrm{mmol} / \mathrm{l} \mathrm{D}$-glucose. In the presence of $\mathrm{Ca}^{2+}$ and at $16.9 \mathrm{mmol} / \mathrm{l} \mathrm{D}$-glucose, it only represented $57.7 \pm 6.7 \%(n=17 ; p<0.005)$ of the mean value found, in the same type of rats, at the low concentration of D-glu$\operatorname{cose}(100.0 \pm 12.3 \% ; n=17)$. This indicates that the preferential stimulation of oxidative glycolysis at the high hexose concentration coincided with a more efficient oxidation of $\left[1-{ }^{14} \mathrm{C}\right]$ pyruvate generated from $\mathrm{D}-\left[3,4-{ }^{14} \mathrm{C}\right]$ glucose and, hence, a lesser fractional conversion of the 2 keto acid to $\mathrm{L}-\left[1-{ }^{14} \mathrm{C}\right] \mathrm{alanine}$.

In sharp contrast to the results obtained for the conversion of D- $\left[3,4-{ }^{14} \mathrm{C}\right]$ glucose to either ${ }^{14} \mathrm{CO}_{2}$ or ${ }^{14} \mathrm{C}$-labelled amino acids, the generation of ${ }^{14} \mathrm{C}$-labelled acidic metabolites, i.e. mainly $\mathrm{L}-\left[1{ }^{14} \mathrm{C}\right]$ lactic acid [14], from $\mathrm{D}-[3,4-$ $\left.{ }^{14} \mathrm{C}\right]$ glucose, when expressed relative to the paired production of ${ }^{3} \mathrm{HOH}$ from $\mathrm{D}-\left[5^{3} \mathrm{H}\right]$ glucose, was higher $(p<0.001)$ in STZ and GK than control rats. Indeed, such paired ratios averaged in the STZ and GK rats, respectively, $162.7 \pm 8.6 \%(n=36)$ and $183.2 \pm 17.0 \%(n=26)$ of the mean corresponding reference value found in control rats $(100.0 \pm 6.6 ; n=36)$. In absolute terms, the reference value in control rats was higher $(p<0.02)$ at low $(16.1 \pm 2.3 \%$; $n=12)$ than high hexose concentration $(9.4 \pm 1.1 \%$; $n=12$ ) and, in the latter case, tended to be increased in the absence of $\mathrm{Ca}^{2+}(12.0 \pm 1.0 \% ; n=12)$. A comparable situation was also observed in both STZ and GK rats.

\section{D- $\left[6-{ }^{14} C\right]$ glucose oxidation}

The generation of ${ }^{14} \mathrm{CO}_{2}$ from $\mathrm{D}-\left[6-{ }^{14} \mathrm{C}\right]$ glucose is currently used to assess the oxidation in the Krebs cycle of glucose-derived acetyl residues [14].

In control rats, the ratio between D-[6- $\left.{ }^{14} \mathrm{C}\right]$ glucose oxidation and $\mathrm{D}-\left[5-{ }^{3} \mathrm{H}\right]$ glucose utilization was higher at 16.9 than $5.1 \mathrm{mmol} / \mathrm{L} \mathrm{D}$-glucose $(p<0.001)$ and, at the high hexose concentration, severely decreased in the absence of $\mathrm{Ca}^{2+}(p<0.001)$. Such changes were less marked and failed to achieve statistical significance in islets from STZ rats. Moreover, in the presence of $16.9 \mathrm{mmol} / 1 \mathrm{D}$-glucose and $1.0 \mathrm{mmol} / 1 \mathrm{Ca}^{2+}$, the oxidation of $\mathrm{D}-\left[6-{ }^{14} \mathrm{C}\right]$ glucose, expressed relative to the paired generation of ${ }^{3} \mathrm{HOH}$ from $\mathrm{D}-\left[5-^{3} \mathrm{H}\right]$ glucose, was significantly lower $(p<0.001)$ in STZ than control rats.

In the GK rats, as in control animals, the ratio between $\mathrm{D}-\left[6-{ }^{14} \mathrm{C}\right]$ glucose oxidation and $\mathrm{D}-\left[5^{-} \mathrm{H}\right]$ glucose utilization was increased $(p<0.001)$ as a result of the rise in hexose concentration and, at the high concentration of glucose, decreased $(p<0.02)$ in the absence of $\mathrm{Ca}^{2+}$. However, the absolute values for such a ratio were invariably lower in GK than control rats ( $p<0.02$ or less). Pooling all available data, the ratio averaged in GK rats $68.8 \pm 4.7 \%$
Table 3. Unpaired ratio between $\mathrm{D}-\left[6-{ }^{14} \mathrm{C}\right] \mathrm{glucose}$ and $\mathrm{D}-[3,4-$ $\left.{ }^{14} \mathrm{C}\right]$ glucose or D-[2 $\left.{ }^{14} \mathrm{C}\right]$ glucose oxidation in islets from control rats, animals injected neonatally with streptozotocin (STZ) and GK rats

\begin{tabular}{lclll}
\hline $\begin{array}{l}\text { Rats } \\
\text { (Type) }\end{array}$ & $\begin{array}{l}\text { D-glucose } \\
(\mathrm{mmol} / 1)\end{array}$ & $\begin{array}{l}\mathrm{Ca}^{2+} \\
(\mathrm{mmol} / \mathrm{l})\end{array}$ & $\begin{array}{l}{\left[6-{ }^{14} \mathrm{C}\right] /\left[3,4-{ }^{14} \mathrm{C}\right]-} \\
\text { glucose } \\
(\%)\end{array}$ & $\begin{array}{l}{\left[6-{ }^{14} \mathrm{C}\right] /\left[2-{ }^{14} \mathrm{C}\right]-} \\
\text { glucose } \\
(\%)\end{array}$ \\
\hline Control & 5.1 & 1.0 & $34.0 \pm 2.5$ & $48.1 \pm 3.4$ \\
& 16.9 & 1.0 & $34.8 \pm 1.4$ & $51.6 \pm 2.4$ \\
& 16.9 & Nil & $30.6 \pm 1.5$ & $43.0 \pm 2.9$ \\
\hline STZ & 5.1 & 1.0 & $45.6 \pm 4.3$ & $54.1 \pm 4.0$ \\
& 16.9 & 1.0 & $38.0 \pm 2.9$ & $44.4 \pm 2.9$ \\
& 16.9 & Nil & $37.6 \pm 2.0$ & $53.4 \pm 3.1$ \\
\hline GK & 5.1 & 1.0 & $26.5 \pm 2.7$ & $31.0 \pm 3.8$ \\
& 16.9 & 1.0 & $40.3 \pm 3.7$ & $37.2 \pm 4.6$ \\
& 16.9 & Nil & $27.9 \pm 5.4$ & $39.6 \pm 7.3$ \\
\hline
\end{tabular}

( $n=27 ; p<0.001$ ) of the corresponding value found in control animals $(100.0 \pm 1.9 \% ; n=36)$.

The ratio between $\mathrm{D}-\left[6-{ }^{14} \mathrm{C}\right] \mathrm{glucose}$ and $\mathrm{D}-\left[3,4-{ }^{14} \mathrm{C}\right] \mathrm{glu}-$ cose oxidation, both expressed relative to the paired generation of ${ }^{3} \mathrm{HOH}$ from $\mathrm{D}-\left[5-{ }^{3} \mathrm{H}\right]$ glucose, reflects the oxidation of glucose-derived acetyl residues in the Krebs cycle relative to their generation in the reaction catalysed by pyruvate dehydrogenase. Except in GK rats, such a ratio failed to be significantly affected by a rise in D-glucose concentration (Table 3 ). At the high concentration of $\mathrm{D}$-glucose, it tended to be lower in the absence than presence of $\mathrm{Ca}^{2+}$. Pooling the data collected in the three groups of rats in islets exposed to $16.9 \mathrm{mmol} / \mathrm{l} \mathrm{D}$-glucose, the ratio between $\mathrm{D}-\left[6-{ }^{14} \mathrm{C}\right]$ glucose and $\mathrm{D}-\left[3,4-{ }^{14} \mathrm{C}\right]$ glucose oxidation averaged in the absence of $\mathrm{Ca}^{2+} 86.9 \pm 5.4 \%$ $(p<0.05)$ of the mean corresponding value found in the presence of $\mathrm{Ca}^{2+}(100.0 \pm 3.9 \%)$. No obvious impairment of the ratio between D- $\left[6-{ }^{14} \mathrm{C}\right]$ glucose and $\mathrm{D}-\left[3,4-{ }^{14} \mathrm{C}\right] \mathrm{glu}-$ cose oxidation was observed in the glucose-intolerant rats. Pooling all available data, such a ratio averaged, in the GK rats, $95.0 \pm 7.5 \%(p>0.5)$ of the corresponding value found in control animals $(100.0 \pm 3.2 \%)$. In the STZ rats, and as judged from data collected in distinct groups of islets, the ratio between D- $\left[6-{ }^{14} \mathrm{C}\right]$ glucose oxidation and $\mathrm{D}-\left[3,4-{ }^{14} \mathrm{C}\right]$ glucose oxidation was slightly higher $(121.9 \pm 5.4 \% ; p<0.001)$ than the mean corresponding control value. As shown in Table 3 , the overall mean absolute value for the ratio between $\mathrm{D}-\left[6{ }^{14} \mathrm{C}\right]$ glucose and $\mathrm{D}-[3$, $\left.4-{ }^{14} \mathrm{C}\right]$ glucose oxidation did not exceed $35.2 \pm 1.1 \%$, suggesting that the major fraction of acetyl residues derived from exogenous D-glucose escaped full oxidation in the Krebs cycle.

\section{D- $\left[2{ }^{14} C\right]$ glucose oxidation}

In pancreatic islets, the contribution of the pentose phosphate pathway to the oxidation of D-glucose is too low to account for any significant production of ${ }^{14} \mathrm{CO}_{2}$ from D-[2$\left.{ }^{14} \mathrm{C}\right]$ glucose, as could otherwise result from the recirculation of hexose 6-phosphates in the pentose shunt [15]. Hence, the conversion of $\mathrm{D}-\left[2-{ }^{14} \mathrm{C}\right]$ glucose to ${ }^{14} \mathrm{CO}_{2}$ can be used to assess the oxidation of the $\mathrm{C}_{1}$ of glucose-derived acetyl residues in the Krebs cycle. It was recently reported 
that, in islets, such an oxidation largely exceeds that of the $\mathrm{C}_{2}$ of the same residues [15].

In the present study, the oxidation of $\mathrm{D}-\left[2-{ }^{14} \mathrm{C}\right]$ glucose was also much higher than that of $D-\left[6-{ }^{14} \mathrm{C}\right]$ glucose $\left(p<0.001\right.$ in all cases). The ratio between D- $\left[6-{ }^{14} \mathrm{C}\right]$ glucose and $\mathrm{D}-\left[2-{ }^{14} \mathrm{C}\right] \mathrm{glucose}$ oxidation, both expressed relative to the paired production of ${ }^{3} \mathrm{HOH}$ from $\mathrm{D}-\left[5-{ }^{3} \mathrm{H}\right]$ glucose, was not vastly different in STZ and control rats, but obviously lower in GK rats. Pooling the data obtained at two D-glucose concentrations and in the absence or presence of $\mathrm{Ca}^{2+}$, such a ratio averaged, in STZ and GK rats respectively, 107.5 $\pm 4.5 \%(p>0.19)$ and $76.2 \pm 7.0 \%(p<0.005)$ of the mean corresponding value found in control rats $(100.0 \pm 3.6 \%)$.

As already noticed in the case of D- $\left[3,4-{ }^{14} \mathrm{C}\right]$ glucose and $\mathrm{D}-\left[6-{ }^{14} \mathrm{C}\right]$ glucose oxidation, the production of ${ }^{14} \mathrm{CO}_{2}$ from $\mathrm{D}-\left[2-{ }^{14} \mathrm{C}\right]$ glucose, when expressed relative to the paired generation of ${ }^{3} \mathrm{HOH}$ from $\mathrm{D}-\left[5-{ }^{3} \mathrm{H}\right]$ glucose, was increased ( $p<0.02$ or less) in response to a rise in hexose concentration and, at the high concentration of D-glucose, decreased in the absence of $\mathrm{Ca}^{2+}(p<0.01$, except in the control rats).

As a rule, the lower oxidation of $\mathrm{D}-\left[6{ }^{-14} \mathrm{C}\right]$ glucose than $\mathrm{D}-\left[2-{ }^{14} \mathrm{C}\right]$ glucose coincided with a higher recovery of ${ }^{14} \mathrm{C}$ labelled metabolites other than ${ }^{14} \mathrm{CO}_{2}$ with the former compared to the latter tracer. For instance, when expressed relative to the paired generation of ${ }^{3} \mathrm{HOH}$ from $\mathrm{D}-\left[5-{ }^{3} \mathrm{H}\right]$ glucose, the net production of ${ }^{14} \mathrm{C}$-labelled amino acids from $\mathrm{D}-\left[2-{ }^{14} \mathrm{C}\right]$ glucose averaged $78.7 \pm 6.4 \%(n=97$; $p<0.005$ ) of the corresponding mean value found with D- $\left[6-{ }^{14} \mathrm{C}\right]$ glucose $(100.0 \pm 3.6 \% ; n=98)$ in islets prepared from the same type of rats and incubated within the same experiment under the same experimental conditions.

\section{Discussion}

The present results indicate that the rate of glycolysis, as judged from the production of ${ }^{3} \mathrm{HOH}$ from $\mathrm{D}-\left[5^{3} \mathrm{H}\right]$ glucose, is not significantly different in islets from STZ or GK and control rats, at least when related to the protein content of the islets. This negative finding strongly suggests that any anomaly in hexose transport, leading for instance to a delayed equilibration of $\mathrm{D}$-glucose concentration across the beta-cell plasma membrane, is not sufficient to account for impaired insulin release under near steadystate conditions. It is known from previous studies that glucose-stimulated insulin release is impaired in the islets from STZ and GK rats $[16,17]$.

Since our metabolic data refer to a mixed population of islet cells as distinct from a pure population of insulin-producing cells, minor differences in the relative contribution of beta cells to the total islet mass could affect selected metabolic variables. However, it should be underlined that the major metabolic phenomenon considered in the present study, namely the $\mathrm{Ca}^{2+}$-dependent preferential stimulation by $\mathrm{D}$-glucose of mitochondrial oxidative events relative to glycolysis, represents an intrinsic characteristic of pure beta cells [18], not observed in purified non-beta islet cells (D. Pipeleers, A. De Vos, F. Schuit and W.J. Malaisse, unpublished observation). Moreover, in the GK rats, the islet insulin content is little affected when related to either the protein or DNA content [17], suggesting a near normal relative contribution of beta cells to the total islet mass.

A reciprocal coupling has been previously documented [12], in islets from normal rats, between mitochondrial oxidative events and ATP-requiring and glucose-responsive functional processes such as active $\mathrm{Ca}^{2+}$ pumping and insulin release. It could be argued that an impairment of the former events may be, at least in part, secondary to the secretory defect. In the present study, however, well-defined anomalies in the ratio between D-glucose oxidation and utilization were also documented in islets incubated in the absence of extracellular $\mathrm{Ca}^{2+}$.

The present findings do not rule out subtle anomalies in the overall glycolytic response of islet cells to a rise in $\mathrm{D}$-glucose concentration. The ratio in glycolytic flux from $16.9 \mathrm{mmol} / \mathrm{l}$ to $5.1 \mathrm{mmol} / \mathrm{l} \mathrm{D}$-glucose was indeed significantly lower in STZ and GK than control rats. However, this anomaly could be the consequence of an impaired stimulation of oxidative glycolysis in the diabetic animals.

In both STZ and GK rats, the ratio between D- $[3,4-$ $\left.{ }^{14} \mathrm{C}\right]$ glucose oxidation and $\mathrm{D}-\left[5-{ }^{3} \mathrm{H}\right]$ glucose conversion to ${ }^{3} \mathrm{HOH}$ was about $25 \%$ lower than in control rats. This suggests a preferential deficiency of the oxidative modality of glycolysis, which is coupled with the transfer of reducing equivalents into the mitochondria, as mediated for instance by the glycerol phosphate shuttle [19] and, hence, not associated with the generation of L-lactate. It has previously been shown that, in STZ rats, this preferential impairment of oxidative glycolysis coincides with a decreased flow through the glycerol phosphate shuttle [20, 21].

In pancreatic islets, the net generation of ${ }^{14} \mathrm{C}$-labelled pyruvate and L-alanine from $\mathrm{D}-\left[3,4-{ }^{14} \mathrm{C}\right]$ glucose is much lower than its oxidation rate [22]. The present study further indicates that, relative to $\mathrm{D}-\left[5-{ }^{3} \mathrm{H}\right]$ glucose utilization, the production of ${ }^{14} \mathrm{C}$-labelled $\mathrm{L}$-alanine from $\mathrm{D}$ - $[3,4-$ ${ }^{14} \mathrm{C}$ ]glucose was significantly lower in STZ or GK than control rats. These findings strongly suggest that the low ratio between $\mathrm{D}-\left[3,4-{ }^{14} \mathrm{C}\right]$ glucose oxidation and $\mathrm{D}-[5$ $\left.{ }^{3} \mathrm{H}\right]$ glucose utilization found in diabetic animals reflects an altered ratio between oxidative and total glycolysis, rather than a primary defect in the activity of pyruvate dehydrogenase. Thus, if the velocity of the reaction catalysed by pyruvate dehydrogenase were to be decreased, without any perturbation in the ratio between oxidative and total glycolysis, an excessive amount of ${ }^{14} \mathrm{C}$-labelled pyruvate and L-alanine would be expected to be generated from D- $\left[3,4-{ }^{14} \mathrm{C}\right]$ glucose.

As judged from the ratio between $D-\left[6-{ }^{14} \mathrm{C}\right]$ glucose and $\mathrm{D}-\left[3,4-{ }^{14} \mathrm{C}\right]$ glucose, the oxidation of acetyl residues in the Krebs cycle, relative to their generation in the reaction catalysed by pyruvate dehydrogenase, was also not impaired in diabetic animals. The absence of any major primary metabolic defect in the Krebs cycle of STZ or GK rats is further supported by the finding that the unpaired ratio between $\mathrm{D}-\left[2-{ }^{14} \mathrm{C}\right]$ glucose and $\mathrm{D}-\left[3,4-{ }^{14} \mathrm{C}\right]$ glucose oxidation was slightly higher in diabetic than control rats. Pooling all available data, such a ratio averaged in STZ and GK rats, respectively, $115.0 \pm 6.0$ and $126.9 \pm 10.1 \%$ 
( $p<0.05$ or less) of the corresponding value found in control rats $(100.0 \pm 3.9 \%)$. The lower ratio between $\mathrm{D}-[6-$ $\left.{ }^{14} \mathrm{C}\right]$ glucose and $\mathrm{D}-\left[2-{ }^{14} \mathrm{C}\right]$ glucose oxidation in the GK rats would then suggest that the influx into the Krebs cycle of 4- or 5-carbon metabolites derived from endogenous unlabelled nutrients is higher, relative to the inflow into the same cycle of acetyl residues, in GK than either control or STZ rats [15].

In conclusion, the present study suggests that in GK as well as in STZ rats, the impaired insulin secretory response to D-glucose might be caused, at least in part, by an altered ratio between oxidative and total glycolytic flux. In the STZ rats, this metabolic anomaly was attributed to a site-specific defect in the activity of the mitochondrial FAD-linked glycerophosphate dehydrogenase $[11,20]$. Further studies, in progress, are required to document whether a comparable enzymatic defect is present in the islets of GK rats. Meanwhile, our findings reveal that a preferential perturbation of oxidative glycolysis in pancreatic islets represents a metabolic feature of non-insulin-dependent diabetes not only in adult rats injected with streptozotocin during the neonatal period (STZ rats) but also in diabetic GK rats obtained by selective breeding over numerous generations $[3,4]$. Therefore, the preferential perturbation of oxidative glycolysis could conceivably represent a mechanism leading to spontaneous, as distinct from drug-induced, non-insulin-dependent diabetes.

Acknowledgements. This work was supported in part by grants from the Institut National de la Santé et de la Recherche Médicale (France), Communauté Française de Belgique (Belgium) and Foundation for Scientific Medical Research (Belgium). We thank Ms D. Bailbe, Ms J. Marchand, Ms J. Schoonheydt, Ms M. Urbain and Mr. G. Vandenbroeck for technical assistance and Ms C.Demesmaeker for secretarial help.

\section{References}

1. Unger RH (1991) Diabetic hyperglycemia: link to impaired glucose transport in pancreatic $\beta$ cells. Science $251: 1200-1205$

2. Leahy JL, Bonner-Weir S, Weir CG (1992) $\beta$-cell dysfunction induced by chronic hyperglycemia. Diabetes Care 15: 442-455

3. Goto Y, Kakizaki M, Masaki N (1975) Spontaneous diabetes produced by selective breeding of normal Wistar rats. Proc Jap Acad 51: 80-85

4. Goto Y, Kakizaki M (1981) The spontaneous-diabetes rat: a model of noninsulin dependent diabetes mellitus. Proc Jap Acad 57: 381-384

5. Portha B, Levacher C, Picon L, Rosselin G (1974) Diabetogenic effects of streptozotocin in the rat during the perinatal period. Diabetes 23: 880-895

6. Portha B, Serradas P, Bailbe D, Suzuki KI, Goto Y, Giroix M-H (1991) B-cell insensitivity to glucose in the GK rat, a spontaneous non obese model for type 2 (non-insulin-dependent) diabetes. Diabetes 40: 486-496

7. Portha B, Picon L, Rosselin G (1979) Chemical diabetes in the adult rat as the spontaneous evolution of neonatal diabetes. Diabetologia 17: 371-377

8. Bergmeyer HU, Berndt E (1974) D-glucose determination with glucose oxidase and peroxidase. In: Bergmeyer HU (ed) Models of enzymatic analysis. Academic Press, New York, pp 1205-1215

9. Leclercq-Meyer V, Marchand J, Woussen-Colle M-C, Giroix MH, Malaisse WJ (1985) Multiple effects of leucine on glucagon, insulin and somatostatin secretion from the perfused rat pancreas. Endocrinology 116:1168-1174

10. Malaisse-Lagae F, Malaisse WJ (1984) Insulin release by pancreatic islets. In: Larner J, Pohl SL (eds) Methods in diabetes research, vol. 1. John Wiley, New York, pp 147-152

11. Giroix M-H, Baetens D, Rasschaert J et al. (1992) Enzymic and metabolic anomalies in islets of diabetic rat: relationship to Bcell mass. Endocrinology 130:2634-2640

12. Malaisse WJ, Sener A (1988) Hexose metabolism in pancreatic islets. Feedback control of D-glucose oxidation by functional events. Biochim Biophys Acta 971:246-254

13. Giroix M-H, Sener A, Pipeleers DG, Malaisse WJ (1984) Hexose metabolism in pancreatic islets. Inhibition of hexokinase. Biochem J 223: 447-453

14. Sener A, Malaisse WJ (1987) Stimulation by D-glucose of mitochondrial oxidative events in islet cells. Biochem J 246: 89-95

15. Malaisse WJ, Sener A (1992) Hexose metabolism in pancreatic islets. Unequal oxidation of the two carbons of glucose-derived acetyl residues. Arch Biochem Biophys 292: 244-249

16. Giroix M-H, Sener A, Bailbe D, Portha B, Malaisse WJ (1990) Impairment of the mitochondrial oxidative response to D-glucose in pancreatic islets from adult rats injected with streptozotocin during the neonatal period. Diabetologia 33: 654660

17. Giroix M-H, Vesco L, Portha B (1992) Functional and metabolic perturbations in isolated pancreatic islets from the GK rat, a genetic model of non-insulin-dependent diabetes. Diabetologia 35 [Suppl 1]: A77 (Abstract)

18. De Vos A, Schuit FC, Malaisse WJ (1991) Preferential stimulation by glucose of its oxidation relative to glycolysis in purified insulin-producing cells. Biochem Int 24: 117-121

19. Rasschaert J, Malaisse WJ (1991) Hexose metabolism in pancreatic islets. Glucose-induced and $\mathrm{Ca}^{2+}$-dependent activation of FAD-glycerophosphate dehydrogenase. Biochem J 278:335-340

20. Giroix M-H, Rasschaert J, Bailbe D et al. (1991) Impairment of glycerol phosphate shuttle in islets from rats with diabetes induced by neonatal streptozotocin. Diabetes 40:227-232

21. Giroix M-H, Rasschaert J, Sener A et al. (1992) Study of hexose transport, glycerol phosphate shuttle and Krebs cycle in islets of adult rats injected with streptozotocin during the neonatal period. Mol Cell Endocrinol 83:95-104

22. Malaisse WJ, Rasschaert J, Conget I, Sener A (1991) Hexose metabolism in pancreatic islets. Regulation of aerobic glycolysis and pyruvate oxidation. Int J Biochem 23: 955-959

Received: 30 September 1992

and in revised form: 26 November 1992

Prof. W.J. Malaisse

Brussels Free University

808 Route de Lennik

B-1070 Brussels

Belgium 